Journal of Molecular and Cellular Cardiology (1976) 8, 1-13

\title{
Metabolism of Palmitaldehyde in Human Gardiac Muscle
}

\author{
WILLIAM J. FERRELL AND KUO-GHING YAO* \\ Departments of Pathology and Biological Chemistry, University of Michigan, Ann Arbor, Michigan \\ 48104, U.S.A.
}

(Received 15 fuly 1974, accepted in revised form 12 February 1975)

\begin{abstract}
W. J. Ferrell ANd K.-C. Yao. Metabolism of Palmitaldehyde in Human Cardiac Muscle. Journal of Molecular and Cellular Cardiology (1976) 8, 1-13. Palmitaldehyde-1-14[C] was incubated with homogenates of human heart and the distribution of radioactivity in the nonpolar and polar lipids was determined. Comparisons between the radioactivity in the acyl, alkyl and alk-l-enyl moieties were evaluated. The role of palmitaldehyde-[l- $\left.{ }^{3} \mathrm{H}\right]-\left[\mathrm{l}^{14} \mathrm{C}\right]$ as a possible precursor of the alk-l-enyl chains was also assessed. A comparison of incorporation into heart lipids was made between labelled palmitate, palmitaldehyde and cetyl alcohol. The following metabolic relationships are suggested from the results:

1. Palmitaldehyde appears to be metabolized by a different route than palmitate and cetyl alcohol.

2. Most of the incorporated palmitaldehyde was found in triglycerides indicating that the aldehyde was oxidized prior to incorporation.

3. At least two pathways exist for the synthesis of alk-l-enyl ethers from aldehydes. One involves reduction to the alcohol and reaction with acyl-dihydroxyacetone phosphate and the second, prior oxidation to the acid followed by incorporation, presumably through the l-acyl linkage.

4. Using the three labelled substrates led to an interrelationship which accounts for all three being incorporated into acyl, alkyl and alk-l-enyl chains.
\end{abstract}

KeY Words: Metabolism; Heart; Palmitate; Palmitaldehyde; Cetyl alcohol; Plasmalogens; Alkyl ethers; Aldehydogenic lipid; Thin-layer chromatography; Gas-liquid chromatography.

\section{Introduction}

The existence of free fatty aldehydes as naturally occurring components of mammalian heart muscle $[8,16,17,25]$ luminous bacteria $[1 I]$ and fruit lipids $[10,28]$ has been demonstrated in recent years. Fatty aldehydes serve as an intermediate in the oxidation level between the corresponding carboxylic acids and alcohols, and the enzymatic interconversion of fatty acids, aldehydes and alcohols has been shown $[7,12,30]$. Other sources of free fatty aldehydes are reduction of the corresponding fatty acyl-CoA $[6,17]$ and cleavage of the ether linkage of alk-l-enyl glycerol ethers and plasmalogens.

The exact function of free fatty aldehydes in mammalian systems has yet to be established. In the light of our previous find that free fatty aldehyde concentration

* Present address: Mayo Clinic, Rochester, Minnesota 55901, U.S.A. 
increased with age in human heart [13] and serum [15] the present work dealing with the metabolism of free fatty aldehydes in human heart was undertaken.

\section{Materials and Methods}

Palmitic acid-[l-14 $\mathrm{C}](53.3 \mathrm{mCi} / \mathrm{mm})$ and cetyl alcohol-[1-14 $\mathrm{C}](11.4 \mathrm{mCi} / \mathrm{mm})$ were purchased from New England Nuclear Corp. and subjected to thin-layer chromatography (t.l.c.) before use. The liquid scintillation cocktail, Aquasol, was also purchased from New England Nuclear. All other chemicals used were of the highest possible purity. Cofactors were purchased from the Sigma Chemical Company. Radiolabeled palmitaldehyde $\left(\left[\mathrm{l}^{14} \mathrm{C}\right], 1.0 \mathrm{mCi} / \mathrm{mm}\right)$ was synthesized as described elsewhere [14]. Palmitaldehyde- $\left[1-{ }^{3} \mathrm{H}\right]-\left[1-{ }^{14} \mathrm{C}\right]$ was prepared by $\mathrm{LiAl}^{3}$ $[\mathrm{H}]_{4}(4.4 \mathrm{mCi} / \mathrm{mm}$, New England Nuclear Corp.), reduction of palmitic acid$\left[{ }^{[1-14} \mathrm{C}\right](1.1 \mathrm{mCi} / \mathrm{mm})[14]$.

The experiments were carried out in sucrose homogenates of human hearts obtained at autopsy and immediately frozen. The hearts were from male patients whose case histories and pathological evidence showed them to be free of myocardial infarction. The ages of the patients were 23, 39 and 59. Data on some of these hearts have already been given [13]. Two of the hearts (23 and 59) were from accident victims and the other was from a patient who died as a result of a brain tumor. All hearts were obtained within a few hours of death. Pericardial fat was removed and the tissue cut into small pieces which were centrifuged at $650 \times g$ for $20 \mathrm{~min}$ to remove cell debris and nuclei. The resulting supernatant was used for the metabolic studies. Incubations were carried out in $10 \mathrm{ml}$ Erlenmeyer flasks using a Dubnoff metabolic shaker at $37^{\circ} \mathrm{C}$ and medium speed for $3 \mathrm{~h}$ (except for the time study experiments). Following incubation the mixtures were quantitatively extracted by the addition of 10 volumes of chloroform-methanol, 2:1. A control was included in each experiment consisting of homogenate boiled for $30 \mathrm{~min}$ plus cofactors and substrate. Each incubation flask contained $0.3 \mathrm{~g}$ of protein and $1 \mathrm{ml}$ of radiolabeled substrate dispersed in $20 \%$ aqueous Tween 20 . Depending on the experiment, the incubation mixture also contained all or some of the following: $1 \mathrm{ml} 0.05 \mathrm{M}$ Tris-HCl buffer, $\mathrm{pH} 7.0 \mathrm{NADH}(1.5 \mu \mathrm{M})$, NADPH $(1.5 \mu \mathrm{M})$, NAD $(1.5 \mu \mathrm{M}), \operatorname{ATP}(3 \mu \mathrm{M}), \mathrm{CoA}(0.2 \mu \mathrm{M}), \mathrm{KCl}(2.0 \mu \mathrm{M})$ and $\mathrm{MgCl}_{2} .6 \mathrm{H}_{2} \mathrm{O}(1.0 \mu \mathrm{M})$. The total volume in all cases was $3 \mathrm{ml}$.

Following extraction from the incubation mixture the lipids were concentrated under vacuum using a Buchii rotary evaporator. The lipids were blanketed under $\mathrm{N}_{2}$ and stored in fresh $\mathrm{CS}_{2}$ at $-20^{\circ} \mathrm{C}$ until used [37]. The total lipids were separated into nonpolar and polar lipids [4] and aliquots removed for radio-assay and other analyses. The nonpolar lipids were further separated on a column $(1.5 \times 20 \mathrm{~cm})$ of 200 to 325 mesh silicic acid. The column was thoroughly prewashed, before applying the samples, first with chloroform and then hexane. 
The first fraction (a) containing long-chain hydrocarbons, wax esters and aldehydes was collected by elution with $200 \mathrm{ml}$ of pure hexane; triglycerides (b) were collected with $200 \mathrm{ml}$ of $2.5 \%$ diethyl ether in petroleum ether and the fraction (c) containing diglycerides, cholesterol, fatty alcohols and acids were collected by elution with $300 \mathrm{ml}$ of chloroform. While this type of column separation did not give pure lipid fractions it did serve to separate the major classes so that the small amounts of minor lipids could be subsequently obtained by t.l.c. Unless otherwise specified, neutral thin layer plates [29] of silica gel $\mathrm{G}$ were used after activation at $110^{\circ} \mathrm{C}$ for $2 \mathrm{~h}$. Fractions (a) and (b) were separated into cholesterol esters, wax esters, free fatty aldehydes, alkyldiacylglycerides and triglycerides using a developing solvent of hexanediethyl ether $(95: 5, \mathrm{v} / \mathrm{v})$ [27]. Fraction (c) was separated using plates of aluminum oxide $\mathrm{H}$ and double development in a solvent system of hexane-ethylacetate $(160: 15, \mathrm{v} / \mathrm{v})$ [12]. Free fatty aldehyde and acid fractions were further purified using hexane-diethyl ether-acetic acid $(70: 30: 1$, $\mathrm{v} / \mathrm{v} / \mathrm{v})$. Polar lipids were separated using chloroform-methanol-water $(65: 25: 4$, $\mathrm{v} / \mathrm{v} / \mathrm{v})[33]$.

For polar lipid samples subjected to reduction with either $\mathrm{LiAlH}_{4}$ or vitride [36] the products, consisting primarily of alk-l-enyl and alkyl glycerol ethers and fatty alcohols, were separated by t.l.c. using either diethyl-ether-water $(100: 0.5 \mathrm{v} / \mathrm{v})$ [36] or petroleum ether-diethyl ether-acetic acid (90:10:1 v/v/v) [22]. Prior to g.l.c. the fatty alcohols were converted to acetyl derivatives [3] and the $\mathrm{O}$-alkyl glycerol ethers were converted to their isopropylidene derivative [35]. The alk-l-enyl glycerol ethers obtained by reduction [36] of the polar lipids were treated with $\mathrm{HCl}$ gas [9] and the liberated fatty aldehydes isolated by t.l.c. [9]. The fatty aldehydes were analyzed by g.l.c. [16].

Free fatty acids were methylated in sealed microflex tubes by heating for $1 \mathrm{~h}$ in a $100^{\circ} \mathrm{C}$ oven in the presence of $2 \mathrm{ml}$ of methanol containing $2 \%$ sulfuric acid $(\mathrm{v} / \mathrm{v})$. The transmethylation of the nonpolar and polar lipid fractions was carried out as described by others [24]. To eliminate contamination with dimethyl acetals, free and bound fatty aldehydes were removed from both lipid fractions prior to methylation. The free aldehydes were removed by t.l.c. [16] and the bound aldehydes also by t.l.c. following exposure to $\mathrm{HCl}$ gas [9].

G.l.c. analyses were carried out using a Packard, Model 7500 instrument with a flame ionization detector and a Model 850 fraction collector. A $6 \mathrm{ft}$ glass column containing 14.5\% EGSS-X on 100 to 120 mesh Gas-Chrom P (Applied Science) was used, with $\mathrm{N}_{2}$ as the carrier gas at a flow rate of $100 \mathrm{ml} / \mathrm{min}$ and an inlet pressure of $31 \mathrm{lbf} / \mathrm{in}^{2} \mathrm{H}_{2}$ and air flow rates were $300 \mathrm{ml} / \mathrm{min}$ and $220 \mathrm{ml} / \mathrm{min}$ respectively. Fatty aldehydes were run isothermally at either $160^{\circ} \mathrm{C}$ or $180^{\circ} \mathrm{C}$. Fatty alcohol acetates and fatty acid methyl esters were run by programming from $160^{\circ} \mathrm{C}$ to $190^{\circ} \mathrm{C}$ at a rate of $2^{\circ}$ per min. Peaks were identified by co-chromatography with known standards and from plots of chain lengths $v$ s the log of the relative retention time. Peak areas were calculated either as the product of the peak height 
and the width at half peak height or by planimetry. Percentages are given in terms of peak areas.

Samples analyzed by g.l.c. were collected, following separation, using the fraction collector. The gas stream emerging from the column was split in the ratio 10:1 (collector: detector). The hot effluent was trapped in short sections of glass tubing containing $p$-terphenyl crystals coated with DC-550 (Packard Instrument Co.). Each cartridge was then placed in a liquid scintillation counting vial, and $15 \mathrm{ml}$ of scintillation cocktail, consisting of $4 \mathrm{~g} \mathrm{2,5-diphenyl-oxazole} \mathrm{(PPO)} \mathrm{and} 50 \mathrm{mg} 1$, 4-bis [2-(4-methyl-5-phenyl oxazole)] benzene (dimethyl POPOP) in 11 of tolune, was added and the vials shaken vigorously. All samples were counted five times for $10 \mathrm{~min}$ in a Packard Tri-Carb, model 3320 spectrometer and the average value determined. Efficiencies and quench determinations, which were usually negligible, were made using an automatic external standard. Total recoveries of radioactivity from the g.l.c. column were between $70 \%$ and $80 \%$. Relative specific activities were taken as the ratio of the $\mathrm{d} / \mathrm{min}$ in the collected fraction to the peak area of that fraction obtained during collection [1].

The radioassay of fatty acid methyl esters was also compared by monitoring the gas during analysis using a F\&M Biochemical Gas Chromatograph Model 400 equipped with a Barber-Colman Radio Activity Monitoring System Model 5190.

The distribution of radioactivity among the various lipids was determined following t.l.c. by scraping the lipid zones into counting vials and adding 15-ml of Aquasol cocktail [20]. In the cxperiments using double labeled substrate, calculations of radioactivity were made as described by Wagner et al. [33]. When both ${ }^{14} \mathrm{C}$ and ${ }^{3} \mathrm{H}$ were counted in the same sample efficiencies of $84 \%$ and $26 \%$ respectively were obtained.

Ester determinations were made as described by Rapport and Alonzo [26]. Free and bound aldehydes were quantitated as hydrazones [8] and protein concentrations were determined by the Lowry method as modified by Miller [23].

Unless otherwise stated, all values reported are the average of at least three experiments using three different hearts.

\section{Results}

\section{Effect of incubation time}

The incorporation of radioactivity from palmitaldehyde-[1-14 $\mathrm{C}]$ into heart lipids varied with time as shown in Table 1 . The greater part of the incorporation appeared to be complete after $15 \mathrm{~min}$ and maximum incorporation became steady at $68 \%$ after $3 \mathrm{~h}$. There was little effect of time on the distribution of radioactivity between the nonpolar and polar lipid fractions although a dramatic increase in total incorporation was observed between 1.5 and $3 \mathrm{~h}$. On the basis of these results all subsequent incubations were carried out for $3 \mathrm{~h}$. 
TABLE 1. Percentage and distribution of palmitaldehyde-[1-14C]* incorporated into human heart total lipid (TL), nonpolar lipid (NPL) and polar lipid (PL) after various time periods

\begin{tabular}{|c|c|c|c|c|}
\hline \multirow[t]{2}{*}{$\begin{array}{l}\text { Incubation } \\
\text { time }(\mathrm{h})\end{array}$} & \multirow{2}{*}{$\begin{array}{c}\text { Corrected } \\
\text { incorporation } \\
\text { into } \mathrm{TL}_{+}^{+} \\
\left(\mathrm{d} / \mathrm{min} \times 10^{5}\right)\end{array}$} & \multicolumn{2}{|c|}{$\begin{array}{l}\text { Distribution } \\
\text { of radioactivity }\end{array}$} & \multirow[t]{2}{*}{$\begin{array}{c}\text { Total } \\
\text { radioactivity } \\
\text { recovered }(\%)\end{array}$} \\
\hline & & NPL & PL & \\
\hline Blank $\uparrow$ & $0.017 \pm 0.003$ & $99.6 \pm 0.5$ & 0.4 & $98.5 \pm 1.1$ \\
\hline 0.08 & $0.821 \pm 0.46$ & $89.3 \pm 2.2$ & 10.7 & $97.3 \pm 2.8$ \\
\hline 0.17 & $1.40 \pm 0.31$ & $79.4 \pm 1.7$ & 20.6 & $101 \pm 1.1$ \\
\hline 0.25 & $2.29 \pm 0.24$ & $68.1 \pm 1.4$ & 31.9 & $92.5 \pm 2.6$ \\
\hline 0.75 & $2.68 \pm 0.22$ & $61.8 \pm 1.6$ & 38.2 & $93.1 \pm 2.1$ \\
\hline 1.5 & $2.57 \pm 0.19$ & $70.5 \pm 1.2$ & 29.5 & $100 \pm 1.2$ \\
\hline 3.0 & $4.06 \pm 0.05$ & $72.5 \pm 1.1$ & 27.5 & $100 \pm 1.1$ \\
\hline 6.0 & $4.03 \pm 0.04$ & $65.4 \pm 1.1$ & 34.6 & $92.0 \pm 2.8$ \\
\hline
\end{tabular}

* Specific activity $1.0 \mathrm{mCi} / \mathrm{mm}$. Incubations contained $0.3 \mu \mathrm{mol}$ of labeled substrate.

$\dagger$ Homogenate boiled for $30 \mathrm{~min}$.

$\ddagger$ Radioactivity recovered as starting precursor has been subtracted.

\section{Palmitaldehyde vs palmitate or cetyl alcohol}

A comparison was made between the incorporation of radiolabeled fatty acid, aldehyde and alcohol into heart lipid. The results are given in Table 2. These results were rather surprising in that palmitaldehyde plus NAD or NADH was a

TABLE 2. Percentage of palmitic acid-[1-14C], cetyl alcohol-[1-14C] and palmitaldehyde- $\left[1-{ }^{14} \mathrm{C}\right]$ incorporated into human heart lipids

\begin{tabular}{|c|c|c|c|c|}
\hline \multirow[t]{2}{*}{$\begin{array}{l}\text { Labeled } \\
\text { substrate }\end{array}$} & \multirow{2}{*}{$\begin{array}{c}\text { Corrected } \\
\text { incorporation } \\
\text { into } \mathrm{TL}^{*} \\
\left(\mathrm{~d} / \mathrm{min} \times 10^{4}\right)\end{array}$} & \multicolumn{2}{|c|}{$\begin{array}{c}\text { Distribution } \\
\text { of radioactivity } \\
(\%)\end{array}$} & \multirow[t]{2}{*}{$\begin{array}{c}\text { Total } \\
\text { radioactivity } \\
\text { recovered }(\%)\end{array}$} \\
\hline & & NPL & PL & \\
\hline Palmitic acid- $\left[1-1^{4} \mathrm{C}\right] \dagger$ & $1.22 \pm 0.63$ & $91.5 \pm 3.7$ & 8.5 & $89.0 \pm 4.6$ \\
\hline Cetyl alcohol- $\left[1-{ }^{4} \mathrm{C}\right]$ & $1.31 \pm 0.47$ & $88.1 \pm 2.9$ & 11.9 & $100 \pm 1.1$ \\
\hline \multicolumn{5}{|l|}{ Palmitaldehyde-[1-14 $\mathrm{C}]$} \\
\hline with NAD & $8.53 \pm 1.22$ & $64.1 \pm 4.2$ & 35.9 & $95.5 \pm 2.3$ \\
\hline NADH & $10.78 \pm 1.54$ & $66.1 \pm 3.8$ & 33.9 & $100 \pm 1.2$ \\
\hline
\end{tabular}

\footnotetext{
* Radioactivity recovered as starting precursor has been subtracted.

$\dagger$ Specific activities: palmitic acid $1.1 \mathrm{mCi} / \mathrm{mm}$; cetyl alcohol $1.2 \mathrm{mCi} / \mathrm{mm}$; palmitaldehyde 0.51 $\mathrm{mCi} / \mathrm{mm}$. Incubations contained $0.1 \mu \mathrm{mol}$ of labeled substrate.
} 
much better precursor of heart total lipids than palmitic acid. Also, we see that with palmitaldehyde three to four times more incorporation was observed in the polar lipids than with either of the other substrates. The addition of unlabeled palmitate or cetyl alcohol (Table 3) caused a decrease in the incorporation of the radioactivity which could be attributed to the nonpolar lipids.

TABLE 3. Incorporation of palmitaldehyde-[1-14 $\mathrm{C}]$, with added unlabeled palmitate and cetyl alcohol, into human heart lipids

\begin{tabular}{|c|c|c|c|c|}
\hline Addition to medium* & $\begin{array}{l}\text { Incorporation } \\
\text { into } \mathrm{TL} \dagger(\%)\end{array}$ & $\begin{array}{l}\text { Distribut } \\
\text { radioactiv } \\
\mathrm{NPL}\end{array}$ & $\begin{array}{l}\text { of } \\
(\%) \\
\text { PL }\end{array}$ & $\begin{array}{c}\text { Total } \\
\text { radioactivity } \\
\text { recovered }(\%)\end{array}$ \\
\hline Palmitaldehyde-[1-14 $\mathrm{C}] \ddagger$ & $84.7 \pm 2.1$ & $71.3 \pm 1.9$ & 28.7 & $94.8 \pm 2.3$ \\
\hline $\begin{array}{c}\text { Palmitaldehyde- }\left[1-{ }^{14} \mathrm{C}\right] \\
+ \\
\text { Palmitate }(20 \mathrm{mg})\end{array}$ & $66.2 \pm 3.7$ & $62.5 \pm 2.6$ & 37.5 & $96.6 \pm 3.7$ \\
\hline $\begin{array}{l}\% \text { Change } \\
\text { Palmitaldehyde- }\left[1-1^{4} \mathrm{C}\right]\end{array}$ & $-18.5 \pm 1.6$ & $-8.8 \pm 0.7$ & +8.8 & \\
\hline $\begin{array}{l}\text { Cetyl alcohol }(20 \mathrm{mg}) \\
\% \text { Change }\end{array}$ & $71.8 \pm 2.4$ & $61.6 \pm 1.7$ & +9.7 & $100 \pm 1.1$ \\
\hline
\end{tabular}

* The medium also contained NADH, CoA, ATP, KCL and $\mathrm{MgCl}_{2}$.

$\dagger$ Radioactivity recovered as starting precursor has been subtracted.

‡ Specific activity $1.0 \mathrm{mCI} / \mathrm{mm}$. Incubations contained $0.3 \mathrm{~mol}$ of labeled substrate.

\section{Palmitaldehyde incorporation into lipids}

When the nonpolar and polar lipid fractions from $3 \mathrm{~h}$ palmitaldehyde-[1-14 $\mathrm{C}]$ incubations were separated into their components the results given in Table 4 were obtained. Only fractions containing $2 \%$ or greater of the incorporated activity are reported. Most of the incorporation occurred in the triglyceride fraction. Thus, it would appear that the palmitaldehyde had been incorporated following enzymatic oxidation. This is further supported by the incorporation into free fatty acids, cholesterol esters and the phosphoglycerides.

When similar experiments were carried out using palmitate-[1-14 $\mathrm{C}]$ and cetyl alcohol-[ $\left[1-{ }^{14} \mathrm{C}\right]$ we found slight incorporation from palmitate into free fatty aldehydes, however, no radioactivity was ever detected in this lipid fraction when cetyl alcohol was used as substrate.

\section{Incorporation into acyl, alkyl and alk-l-enyl chains}

The distribution of radioactivity into the acyl, alkyl and alk-l-enyl moieties of the polar lipids was determined following reduction with vitride [36] and isolation of the above reduction products by t.l.c. $[22,36]$. The effects of various coenzymes as 
TABLE 4. Incorporation of radioactivity from palmitaldehyde-[1-14C] into various lipid classes by heart homogenates*

\begin{tabular}{llrr}
\hline \multirow{2}{*}{ Fraction } & \multicolumn{1}{c}{ Lipid class } & $\mathrm{d} / \mathrm{min} \times 10^{2}$ & Distribution (\%) \\
& & $284 \pm 46$ & $7.0 \pm 0.4$ \\
& Free fatty acid & $2080 \pm 172$ & $51.2 \pm 2.2$ \\
NPL & Triglyceride & $134 \pm 31$ & $3.3 \pm 0.3$ \\
& Glycerol ether diesters & $345 \pm 53$ & $8.5 \pm 0.3$ \\
& Cholesterol ester & $101 \pm 28$ & $2.5 \pm 0.4$ \\
& Other NPL & $353 \pm 48$ & $8.7 \pm 0.1$ \\
& Choline phosphoglyceride & $483 \pm 51$ & $11.9 \pm 0.9$ \\
PL & Ethanolamine phosphoglyceride & $85 \pm 18$ & $2.1 \pm 0.3$ \\
& Serine phosphoglyceride & $203 \pm 80$ & $5.0 \pm 1.3$ \\
\hline
\end{tabular}

* Incubations were for $3 \mathrm{~h}$ at $37^{\circ} \mathrm{C}$ using pamitaldehyde with a specific activity of $1.0 \mathrm{mCi} / \mathrm{mm}$. The incubation medium also contained $\mathrm{CoA}, \mathrm{ATP}, \mathrm{NADH}, \mathrm{NAD}, \mathrm{MgCl}_{2}$ and $\mathrm{KCl}$ (See text for amounts). Results represent the average of four experiments.

well as a comparison between palmitate, palmitaldehyde and cetyl alcohol as potential precursors were evaluated using a $3 \mathrm{~h}$ incubation. These results are presented in Table 5 . In all cases the largest proportion of the radioactivity was

TABLE 5. Distribution of radioactivity among acyl, alkyl and alk-l-enyl moieties of polar lipids (PL) following incubation of palmitaldehyde-[1-14C] with various coenzymes and substrates*

\begin{tabular}{|c|c|c|c|c|c|c|c|}
\hline \multirow{2}{*}{$\begin{array}{l}\text { Additions } \\
\text { None }\end{array}$} & \multirow{2}{*}{$\begin{array}{c}\begin{array}{c}\text { Total } \\
\text { incorporation } \\
\text { into } \mathrm{PL} \\
(\mathrm{d} / \mathrm{min} \times \\
\left.10^{2}\right)\end{array} \\
546 \pm 32\end{array}$} & \multicolumn{2}{|l|}{ Acyl } & \multicolumn{2}{|c|}{$\begin{array}{c}\text { Akyl } \\
\min \times 10^{2} r\end{array}$} & \multicolumn{2}{|c|}{$\begin{array}{c}\text { Alk-l-enyl } \\
\left(\mathrm{d} / \mathrm{min} \times 10^{2} \text { ratio }\right)\end{array}$} \\
\hline & & $340 \pm 26$ & - & $31 \pm 8$ & - & $25 \pm 4$ & - \\
\hline NAD & $1838 \pm 94$ & $1440 \pm 143$ & 4.2 & $93 \pm 4$ & 3.0 & $68 \pm 9$ & 2.7 \\
\hline NADH & $3038 \pm 103$ & $1917 \pm 184$ & 5.6 & $297 \pm 32$ & 9.5 & $285 \pm 43$ & 11.4 \\
\hline NADPH & $1632=155$ & $899+96$ & 2.6 & $236+43$ & 7.6 & $221 \pm 36$ & 8.8 \\
\hline $\begin{array}{l}\mathrm{NADH}+\mathrm{CoA} \dagger \\
\mathrm{NADH}+\mathrm{CoA}+\end{array}$ & $793 \pm 81$ & $487 \pm 56$ & 1.4 & $75 \pm 9$ & 2.4 & $68 \pm 9$ & 2.7 \\
\hline $\begin{array}{l}+ \\
\text { Palmitic acid }(20 \mathrm{mg}) \\
\text { NAD + CoA } f\end{array}$ & $2563 \pm 147$ & $1666 \pm 122$ & 4.9 & $89 \pm 7$ & 2.9 & $66 \pm 8$ & 2.6 \\
\hline $\begin{array}{c}+ \\
\text { Cetyl alcohol }(20 \mathrm{mg})\end{array}$ & $2867 \pm 134$ & $1777 \pm 156$ & 5.2 & $393 \pm 87$ & 12.7 & $97 \pm 9$ & 3.9 \\
\hline
\end{tabular}

* Incubations were for $3 \mathrm{~h}$ at $37^{\circ} \mathrm{C}$ using $0.3 \mu \mathrm{mol}$ of palmitaldehyde-[l-14 $\mathrm{C}$, specific activity $1.0 \mathrm{mCi} / \mathrm{mm}$.

$\dagger$ The medium also contained ATP, $\mathrm{KCl}, \mathrm{MgCl}_{2}$. (See text for amounts.)

$\$ \mathrm{~d} / \mathrm{min}$ with addition $\div \mathrm{d} / \mathrm{min}$ no addition. 
found in the acyl chains of the polar lipids. The proportion of radioactivity in both the alkyl and alk-l-enyl chains increased about nine-fold in the presence of NADPH and about ten-fold with NADH, however, with NADH plus CoA and other cofactors the increase was only about three-fold. CoA appeared to inhibit the incorporation of aldehyde into acyl chains. The addition of excess unlabeled palmitate to the NADH plus CoA had little effect on the proportion of radioactivity in the alkyl and alk-l-enyl chains but did allow more aldehyde to be incorporated into acyl chains. Excess unlabeled cetyl alcohol also gave an increase in incorporation into all the fatty chains although the most dramatic effect was on the alkyl groups.

The effect of added unlabeled palmitate or cetyl alcohol was evaluated more directly by g.l.c. The 16:0 component of the various fatty moieties was collected and the relative specific activity determined. These results are given in Table 6 .

TABLE 6. Effect of palmitate and cetyl alcohol on the incorporation of palmitaldehyde$[1-14 \mathrm{C}]$ into the $16: 0$ component of various fatty chains

\begin{tabular}{|c|c|c|c|c|c|c|c|c|c|}
\hline \multirow[b]{3}{*}{ Condition } & \multicolumn{9}{|c|}{ Relative specific activity of $16: 0$ moiety } \\
\hline & \multirow{2}{*}{$\begin{array}{l}\text { Free } \\
\text { acid }\end{array}$} & \multirow{2}{*}{$\begin{array}{l}\text { Free } \\
\text { aldehyde }\end{array}$} & \multirow{2}{*}{$\begin{array}{l}\text { Free* } \\
\text { alcohol }\end{array}$} & \multicolumn{2}{|c|}{ Acyl } & \multicolumn{2}{|c|}{ Alkyl } & \multicolumn{2}{|c|}{ Alk-l-enyl } \\
\hline & & & & NPL & PL & NPL & PL & NPL & PL \\
\hline $\begin{array}{l}\text { Palmitaldehyde- } \\
{\left[11^{14} \mathrm{C}\right]}\end{array}$ & 7.7 & 20.3 & 4.8 & 53.2 & 18.2 & 10.2 & 8.1 & 11.3 & 17.8 \\
\hline $\begin{array}{c}\text { Palmitaldehyde- } \\
\begin{array}{c}{\left[1-{ }^{14} \mathrm{C}\right]} \\
+\end{array} \\
\text { Palmitate }\end{array}$ & $-\dagger$ & 18.9 & 4.7 & 3.6 & 7.5 & 6.7 & 4.9 & 6.1 & 10.2 \\
\hline $\begin{array}{l}\text { Change (\%) } \\
\text { Palmitaldehyde- }\end{array}$ & & -7 & -2 & -93 & -59 & -34 & -39 & -46 & -43 \\
\hline $\begin{array}{c}{\left[1-{ }^{14} \mathrm{C}\right]} \\
+\end{array}$ & 3.6 & 20.9 & $-\dagger$ & 26.9 & 19.0 & 5.4 & 3.6 & 3.8 & 4.5 \\
\hline $\begin{array}{l}\text { Cetyl alcohol } \\
\text { Change }(\%)\end{array}$ & -53 & 0 & & -49 & +4 & -47 & -56 & -66 & -75 \\
\hline
\end{tabular}

* Unlabeled cetyl alcohol added as carrier following incubation.

$\dagger$ Not determined due to added unlabeled precursor.

The relative specific activity of the latter was essentially unchanged by the addition of unlabeled 16:0 acid. The relative specific activity of the 16:0 aldehyde did not change significantly by the addition of either unlabeled 16:0 acid or alcohol. These results suggest that the equilibrium lies away from the aldehyde towards either the acid or alcohol.

The dilutions in radioactivity of the 16:0 component of the acyl, alkyl and alk-1- 
enyl moictics following the addition of cetyl alcohol or palmitate suggest that they are being used competitively with the aldehyde for the biosynthesis of these lipid chains, or that they are competing for a necessary cofactor.

To further answer this question the incubations using palmitaldehyde-l- ${ }^{3} \mathrm{H}-\left[1-{ }^{14} \mathrm{C}\right]$ were made. Following incubation, at two different times, the ${ }^{3} \mathrm{H}:{ }^{14} \mathrm{C}$ ratios of the polar lipid acyl, alkyl and alk-l-enyl chains were determined. These results are given in Table 7 . As expected most of the ${ }^{3} \mathrm{H}$ was lost in the acyl groups but only

TABLE 7. Comparison of ${ }^{3} \mathrm{H}:{ }^{14} \mathrm{C}$ ratios of acyl, alkyl and alk-l-enyl moieties of polar lipids following incubation with palmitaldehyde- $\left[1-{ }^{3} \mathrm{H}\right]-\left[1-{ }^{14} \mathrm{G}\right]$

\begin{tabular}{cccc}
\hline $\begin{array}{c}\text { Incubation } \\
\text { Time } \\
(\mathbf{h})\end{array}$ & Acyl & $\begin{array}{c}{ }^{\mathbf{3}} \mathbf{}^{14} \mathbf{C} \text { Ratio* } \\
\text { Alkyl }\end{array}$ & Alk-1-enyl \\
& & & \\
0.5 & 0.8 & 2.9 & 2.1 \\
3.0 & 0.6 & 3.2 & 2.4 \\
\hline
\end{tabular}

${ }^{*}{ }^{3} \mathrm{H}:{ }^{14} \mathrm{C}$ ratio of substrate was 3.9 .

about $50 \%$ loss of ${ }^{3} \mathrm{H}$ occurred in the alk-l-enyl chains. Thus fatty acids appear to play some role in the biosynthesis of the alk-l-enyl bond of plasmalogens or a greater percentage of ${ }^{3} \mathrm{H}$ should have been lost. Since approximately $80 \%$ of the ${ }^{3} \mathrm{H}$ was retained in the alkyl ether moieties, it is suggested that aldehydes are primarily reduced to alcohols prior to incorporation into O-alkyl glycerol ethers.

\section{Discussion}

The time study (Table 1) shows that maximum incorporation of palmitaldehyde[1-14 C] occurred after $3 \mathrm{~h}$. Using this time, two other precursors, palmitate-[1-14C] and cetyl alcohol-[1-14C], were also studied. It was found that palmitaldehyde[1-14C] was incorporated into lipids to a greater extent than either of the other substrates (Table 2). However, it should be recognized that this may be true only for the $3 \mathrm{~h}$ incubation time, since a complete time study was not performed on the other substrates. In mouse liver, for example, maximum interconversion of fatty acids, aldehydes and alcohols occurred in less than $1.5 \mathrm{~h}$, when starting with radiolabeled palmitate [12].

The greater incorporation of palmitaldehyde over palmitate or cetyl alcohol (Table 2) and the competitive experiment (Table 3), would suggest that there exists a metabolic pathway for fatty aldehydes different from that of the acid or alcohol in addition to those pathways which may be the same. When 20 times as 
much unlabcled palmitatc or cctyl alcohol was added to the incubation media containing labeled palmitaldehyde the change in either the total incorporation of the aldehyde or in the distribution of the incorporated activity between nonpolar and polar lipids, was not as great as one would expect if only metabolic pathways which were the same for all three compounds existed or they were operating through a common intermediate.

Radioactivity from palmitaldehyde- $\left[1-{ }^{14} \mathrm{C}\right]$ was incorporated into nonpolar and polar lipids with results similar to that observed by others in Ehrlich ascites cells [38]. Our studies indicate that most of the radioactivity from palmitaldehyde was found in lipids containing ester linkages (Table 4). Radiolabeled free fatty acids were isolated, but only very small percentages of radiolabeled free fatty alcohols were detected. Thus it appears that palmitaldehyde was primarily converted to fatty acid and to only a small extent reduced to alcohols. This is also shown by the data in Table 5 using various cofactors. When excess cold palmitate was added to incubations containing labeled palmitaldehyde it was primarily the incorporation into the acyl groups which was affected.

The slight incorporation of palmitate-[l-14 $\mathrm{C}]$ into free fatty aldehydes and the lack of incorporation of cetyl alcohol-[ $\left[1-{ }^{-14} \mathrm{C}\right]$ into free fatty aldehydes suggests that in human heart the interconversion among these three lipids is as follows:

$\mathrm{R}-\mathrm{CO}_{2} \mathrm{H} \leftrightharpoons-\mathrm{RCHO} \leftrightharpoons-?$ - $-\mathrm{R}-\mathrm{CH}_{2} \mathrm{OH}$

This is different from that proposed for either mouse preputial gland tumors [30] or normal mouse liver [12], and the reason may well be the absence of alcohol dehydrogenase in heart muscle [21].

In Ehrlich ascites cells it was shown that fatty acids were precursors of long chain alcohols which were then incorporated in alkyl glycerol ethers [38]. These alkyl glycerol ethers were then found to be precursors of the alk-l-enyl glycerol ethers. Our experiments here support this idea. For example, first we see in Table 5 that in all cases the radioactivity of the alkyl ethers is greater than that of the alk-l-enyl ethers. That in heart tissue there is ten times more alk-l-enyl than alkyl ether $[18]$ adds even more significance to the radioactivity data. Secondly, the experiments with the double labeled palmitaldehyde $\left({ }^{3} \mathrm{H}\right.$ and $\left.{ }^{14} \mathrm{C}\right)$ would further suggest a similar system in human heart. However, the fact that only $50 \%$ loss of ${ }^{3} \mathrm{H}$ occurred in the alk-1-enyl chains also suggests an alternate pathway involving fatty acids directly, perhaps by reduction of the 1-acyl moieties as suggested by others [1].

The evidence here does, however, argue against those mechanisms suggested by Bell and White [2] and Carr et al. [5]. Bell and White [2] showed that, in the developing rat brain, long chain aldehydes are direct precursors of the alk-l-enyl linkage and that oxidation to the acid is not a prerequisite. Carr et al. [5], also working with rat brain, found that palmitaldehyde was not incorporated into the plasmalogen ether linkage, but that palmitate and stearate were incorporated to a limited extent. 
Comparison of the data from Tables 5 and 7 could lead to contradictory results. In Table 5 since the incorporation into alkyl ethers from palmitaldehyde- $\left[1-{ }^{14} \mathrm{C}\right]+$ NADH + CoA is increased by adding cold excess cetyl alcohol it would appear that cetyl alcohol is an unlikely precursor of the alkyl chain. Conversely, from the same Table, the incorporation into the aldehydogenic linkage also drops. One might interpret this as a cetyl alcohol requirement for the aldehydogenic linked chain but not for the saturated alkyl ether. However the experiments (Table 7) with the double labeled palmitaldehyde say that cetyl alcohol is incorporated into both ether moieties. One possible explanation is that in the experiment with excess cold cetyl alcohol we are seeing the results of an equilibrium between the cold alcohol and labeled aldehyde to give an aldehyde pool of lesser specific activity. Furthermore, this equilibrium occurs at a faster rate than does the incorporation of the alcohol into alkyl ethers.

Since it has been established that alkyl glycerol ethers are synthesized by an exchange between long chain fatty alcohol and acyl-dihydroxyacetone phosphate [32] the source of the fatty alcohols becomes important. The incubations involving palmitaldehyde- $\left[1-{ }^{3} \mathrm{H}\right]-[1-14 \mathrm{C}]$ showed that about $80 \%$ of the ${ }^{3} \mathrm{H}$ was found in the alkyl ethers. Thus reduction of the aldehyde to the alcohol may be an important pathway. That cardiac muscle has the ability to reduce fatty acids to fatty aldehydes has already been demonstrated $[7,19]$.

\section{Acknowledgements}

This investigation was supported, in part, by U.S. Public Health Service Grants HL-13361-01-03 and HL-16200-01. Part of this work was conducted while the authors were associated with the Department of Chemistry, University of Detroit, Detroit, Michigan.

\section{REFERENCES}

1. Baumann, N. A., Hagen, P. O. \& Goldfine, H. Phospholipids of Clostridium butyricum: studies on plasmalogen composition and biosynthesis. Journal of Biological Chemistry 240, 1559-1567 (1965).

2. BELL, O. E., JR, \& WHITE, H. B., JR. Plasmalogen metabolism in developing rat brain: aldehydes as a direct precursor in the formation of the vinyl ether linkage. Biochimica et biophysica acta 164, 441-444 (1968).

3. Blank, M. L. \& SNYDER, F. Long chain fatty alcohols in normal and neoplastic tissues. Lipids 5, 337-341 (1970).

4. Borgström, B. Investigation on lipid separation methods. Lipid separation of phospholipid from neutral fat and fatty acids. Acta physiologica scandinavia 25, 101-110 (1952).

5. Garr, H. G., Haerle, H. \& Eiler, J. J. Phospholipid and plasmalogen synthesis in rat-brain homogenates. Biochimica et biophysica acta 70, 205-207 (1963). 
6. Day, J. I. E., Goldfine, H. \& HaGen, P.-O. Enzymic reduction of long chain acylCoA to fatty aldehydes and alcohol by extracts of Clostridium butyricum. Biochimica et biophysica acta 218, 179-182 (1970).

7. Ferrell, W. J. \& Gilbertson, J. R. Enzymatic synthesis of long chain free fatty aldehydes. Proceedings of the West Virginia Academy of Science 39, 363-366 (1967).

8. Ferrell, W. J., RadlofF, J. F. \& JAGKiw, A. B. Quantitative analysis of free and bound fatty aldehydes: optimum conditions for $p$-nitrophenylhydrazone formation. Lipids 4, 278-282 (1969).

9. Ferrell, W. J., Radloff, D. M. \& Radloff, J. F. Method for the hydrolysis and isolation of plasmalogen-bound fatty aldehydes. Analytical Biochemistry 37, 227-235 (1970).

10. Ferrell, W. J. \& Drouillard, M. Long chain free fatty aldehydes in fruit lipids. Physiological Chemistry and Physics 2, 168-170 (1970).

11. Ferreit, W. J., Kessler, R. J. \& Drouillard, M. Identification of n-nonaldehyde in Photobacterium fisheri. Chemistry and Physics of Lipids 6, 131-134 (1971).

12. Ferrell, W. J. \& Kessler, R. J. Enzymic relationship of free fatty acids, aldehydes and alcohols in mouse liver. Physiological Chemistry and Physics 3, 549-558 (1971).

13. Ferrell, W. J. \& RadlofF, J. F. Aldehydogenic lipids of human heart: quantitative and qualitative comparisons between normal and infarcted tissue. International Fournal of Biochemistry 3, 498-502 (1972).

14. Ferrell, W. J. \& YAO, K.-C. Reductive and oxidative synthesis of saturated and unsaturated fatty aldehydes. Fournal of Lipid Research 13, 23-26 (1972).

15. Ferrell, W. J. \& Prmputkar, M. Aldehydogenic lipids in human serum: comparisons of age, sex and heart disease. Fournal of the American Oil Chemists Society 50, Abstract, 62 (1973).

16. Gilbertson, J. R., Ferrell, W. J. \& Gelman, R. A. Isolation and analysis of free fatty aldehydes from rat, dog and bovine heart muscle. Journal of Lipid Research $\mathbf{8}$, 38-45 (1967).

17. Gilbertson, J. R., Johnson, R. C., Gelman R. A. \& Buffenmyer, G. Natural occurrence of free fatty aldehydes in bovine cardiac muscle. Journal of Lipid Research 13, $491-499$ (1972).

18. Horrocks, L. A. Content, composition, and metabolism of mammalian and avian lipids that contain ether groups. In Ether Lipids, Chemistry and Biology, F. Snyder, Ed. p. 177. New York: Academic Press (1972).

19. Johnson, R. C. \& Gilbertson, J. R. Isolation, characterization and partial purification of a fatty acyl coenzyme of reductase from bovine cardiac muscle. Fournal of Biological Chemistry 52, 498-499 (1970).

20. Kritchevsky, D. \& Malhotra, S. Recovery of lipids from thin-layer chromatography for radioassay. Fournal of Chromatography 52, 498-499 (1970).

21. Lochner, A., Cowley, R. \& Brink, J. Effect of ethanol on metabolism and function of perfused rat heart. American Heart Fournal 78, 770-780 (1969).

22. Metcalf, L. D., Schmitz, A. A. \& Pelka, J. R. Rapid preparation of fatty acid esters from lipids for gas chromatographic analysis. Analytical Chemistry 38, 514-515 (1966).

23. Miller, G. L. Protein determination for large numbers of samples. Analytical Chemistry 31, 964 (1959).

24. Morin, R. J., Bermick, S., Mead, J. \& Alfin-Slater, R. B. The influence of exogenous cholesterol on hepatic lipid composition of the rat. Fournal of Lipid Research 3, 432-438 (1962).

25. Radloff, J. F. \& Ferrell, W. J. Qualitative and quantitative analysis of free fatty aldehydes in human heart. Physiological Chemistry and Physics 2, 105-109 (1970). 
26. Rapport, M. \& Alonzo, N. Photometric determination of fatty acid ester groups in phospholipids. Journal of Biological Chemistry 217, 193-198 (1965).

27. Sansone, G. \& Hamilton, J. G. Glyceryl ethers, wax ester and triglyceride composition of the mouse preputial gland. Lipids 4, 435-440 (1969).

28. Schmid, H. H. O. \& BANd, P. C. n-Triacontanal and other long-chain aldehydes in the surface lipids of plants. Hoppe-Seyler's Zeitschrift für physiologische Chemie 350, 462-466 (1969).

29. Skipsky, V. P., Peterson, R. F. \& Barclay, M. Separation of phosphatidyl ethanolamine, phosphatidyl serine and other phospholipids by thin-layer chromatography. Journal of Lipid Research 3, 467-470 (1972).

30. Snyder, F. \& Malone B. Enzymic interconversion of fatty alcohols and aldehydes. Biochemical and Biophysical Research Communications 41, 1382-1387 (1970).

31. Snyder, F., Blank, M. L. \& Wykle, R. L. The enzymic synthesis of ethanolamine plasmalogens. Journal of Biological Chemistry 246, 3639-3645 (1971).

32. SNYDER, F. The enzymic pathways of ether linked lipids and their precursors. In Ether Lipids, Chemistry and Biology, F. Snyder, Ed. p. 121. New York: Academic Press (1972).

33. Wagner, H., Hörhammer, L. \& WolfF, P. Dunnschichtchromatographie von Phosphatiden und Glykolipiden. Biochemische Zeitschrift 334, 175-184 (1961).

34. WebB, R. A. \& METTRICk, D. F. Quantitative lipid scintillation radioassay of phospholipids from thin-layer chromatograms. Journal of Chromatography 67, 75-80 (1972).

35. Woon, R. GLC and TLC analysis of isopropylidene derivatives of isomeric polyhydroxy acids derived from positional and geometrical isomers of unsaturated fatty acids. Lipids 2, 199-203 (1967).

36. Wood, R. \& SNyder, F. Quantitation and determination of alk-l-enyl and alkyl glyceryl ethers in neutral lipids and phospholipids. Lipids 3, 129-135 (1968).

37. WOOD, R. \& HARLow, R. D. Gas-liquid chromatographic analysis of free long-chain aldehydes. Journal of Lipid Research 10, 463-465 (1969).

38. Wood, R. \& Healy, K. Tumor lipids: biosynthesis of plasmalogens. Journal of Biological Chemistry 245, 2640-2648 (1970). 